\title{
DROOLING IN CEREBRAL PALSY
}

\author{
AUDREY SHAVELL, B.A. LOGOPAEDICS (WITWATERSRAND) \\ Senior Speech Therapist, Forest Town Cerebral Palsy School, \\ Forest Town, Johannesburg
}

\section{SUMMARY}

A review of methods of treatment used over the past twelve years in the alleviation of Drooling in Cerebral Palsy is considered. A small group of patients remain persistent droolers in spite of intensive conservative treatment. Information was obtained on patients who had been referred for oral surgery between October 1973 - December 1976 to determine whether any common factors would be found among them which might assist in the selection of future cases for oral surgery; predict the outcome of future surgery more accurately; assess the improvement achieved in the twenty cases of this series; and indicate post-operative complications.

Data was obtained from an analysis of the results of a questionnaire completed by speech therapists on patients who had all undergone bilateral submaxillary gland excision combined with parotid duct elongation and posterior relocation. The oral surgery was carried out by the late Dr. Isidore Kaplan formerly honorary plastic surgeon, Forest Town Cerebral Palsy School.

\section{OPSOMMING}

Die kwylprobleem by die Serebraalverlamde, en die behandeling daarvan gedurende die afgelope 12 jaar word in hierdie studie in oorsig geneem. 'n Klein aantal pasiënte hou aan met kwyl tenspyte van intensiewe konserwatiewe behandeling. Dit sou dus tot die terapeut se voordeel strek om meer inligting te hê van die pasiènte wat gedurende die tydperk Oktober 1973 tot Desember 1976 vir mondchirurgie verwys is, om vas te stel of daar enige faktore was wat die pasiënte in gemeen gehad het en om dus voortaan keuring vir mondchirurgie te vergemaklik deur 'n meer objektiewe standaard daar te'stel en 'n prognose te kan mak. Die algemene vordering van die 20 pasiënte wat mondchirurgie ontvang het, en enige komplikasies wat ingetree het na die operasie word ondersoek. Die inligting vir die studie is verkry deur die analise van 'n vraelys wat voltooi is deur die spraakterapeute wat bogenoemde pasiënte behandel het.

Die chirurgie is uitgevoer deur wyle Dr. Isidore Kaplan, voormalige ereplastiese chirurg, Forest Town Skool vir Serebraalverlamde Kinders.

The problem of drooling in Cerebral Palsy has troubled therapists working in this field for many years. Severe drooling is usually found in those patients who are unable to communicate orally or in those with serious dysarthric bulbar involvements. Over the years various approaches have been tried. Examples of these are:-

1. Constant reminders to patients to close their mouths, suck up and swallow their saliva.

2. Mirror work to draw their attention to the escape of saliva and wet chins as many have, or seem to have, a sensory loss.

3. Conscious use of a 'head back' posture, mouth closure and conscious swaliowing for increasing lengths of time. 
4. Carefully graded feeding programmes to improve co-ordinated activity of lips, tongue, jaws and cheek musculature on a vegetative level emphasizing posterior placement of food on insertion and insistence on a swallow between each mouthful of food. ${ }^{14}$

5. Hard food programmes. ${ }^{11}$

6. An adaptation of a device to control extensor thrust of the mandible suggested by Westlake and Rutherford. 16 Perspex chin cups were individually fitted and moulded to the shape and size of each child's chin. Holes were carefully drilled into the chin cups to allow air to enter and circulate. The chin cups were attached to a headband and when correctly worn facilitated mouth closure and hopefully swallowing. Most patients found the appliance very difficult to tolerate. In thefew who were able to tolerate the appliance, it was found that it kept their mouths closed (opposite to their habitual open mouth posture) but did not in any way facilitate swallowing or reduce the pooling of saliva. Saliva escaped from the corners of the lips, accumulated in the perspex chin cups and excoriation on the chin usually increased so this was soon abandoned.

7. Regular inclusion of sour liquids in the child's daily diet to actually increase salivation and voluntary swallowing. A dessertspoon of lemon juice was given four times a day. The sour taste causes an involuntary sucking in of cheek and lip muscles and a swallow. One patient showed a definite improvement in control of drooling for 15-30 minutes after drinking the lemon juice but then complained of stomach pains. Control of drooling regressed to the pre-treatment state after the initial state of improvement.

8. Encouraging the child to have all liquids and semi-liquid foods (like soups, porridge, custard) through a plastic tube or straw to improve functioning of lip musculature and better co-ordinate sucking and swallowing movements.

9. Teaching the child to chew chewing or bubble gum, under supervision, to increase awareness of oral muscle functioning and develop mouth closure.

10. Operant procedures to eliminate drooling in one cerebral palsied adolescent were successfully used by Garber. ${ }^{5}$

11. Mueller's application of neuro-developmental principles to speech therapy, and specifically her approach of trying to achieve saliva control through feeding and drinking therapy, has been extensively used since early 1974.8, 9, 10 Her approach is based on normalizing muscle tone throughout the body. Particular attention is paid to head, neck and trunk position while muscle tone is reduced in oral areas (in the case of the spastic) and more normal swallowing patterns are facilitated. Normalizing the response to intra-oral digital stimulation and facilitating mouth closure forms part of Helen Mueller's pre-speech therapy programme. In all phases of her 'mouth' therapy. she frequently interrupts the particular activity to facilitate swallowing. She suggests 
various specific methods to overcome drooling by developing mouth closure and eliciting a swallow which all staff members should include in their handling of the patient. The child's attention is never drawn to the drooling as Mueller believes it overburdens the child to expect him to consciously think of swallowing.

12. Sensory stimulation techniques - icing, brushing and resistance techniques applied in and around the mouth to increase sensory awareness, improve mouth closure and swallowing in carefully selected patients. ${ }^{13}$

The latter two methods (oral stimulation and sensory stimulation) have been most successful when combined with graded feeding programmes in those patients treated from a very young age on neuro-developmental lines. However, even in some of-these cases, when they begin walking or the amount of walking increases, a deterioration in control of drooling occurs, ${ }^{10}$ and one has to reintroduce drooling therapy. Control of drooling may also break down when the child is involved in fine motor activities/classwork etc.

13. Medical treatment used has been atropine type drugs to actually reduce the flow of saliva to try and 'dry up' these patients. These proved to be unsuitable because of the relatively large doses required and the side effects.

Other medical and surgical approaches reported in the literature include division of the auriculotemporal nerve and submandibular ganglion of the tympanic plexus - this works temporarily but drooling recurs. Sectioning of the chorda tympani nerve may result in loss of taste sensation, though it is claimed that this eventually does return. ${ }^{4}$

Diamant and Kumlein ${ }^{3}$ excised the sub-mandibular gland on one side and the chorda tympani on the contralateral side within the middle ear. The results of surgery on 12 mentally retarded cerebral palsied patients aged 3-17 years over a two-year period, revealed that five patients were free of symptoms, three patients showed considerable improvement and four patients showed slight improvement.

Parotid duct ligation works, but has a high incidence of refistulization and parotitis. ${ }^{1}$

Worster - Drought ${ }^{19}$ described various medical and surgical procedures used with patients suffering from suprabulbar paresis who were severe droolers. These are illustrated in his description of the treatment of Case VII, ' $J$ ' an eight year old child diagnosed as a case of congenital suprabulbar paresis who was a severe drooler with extremely dysarthric speech.

An attempt was made to relieve the persistent dribbling by prescribing atrophine sulphate (1/100 grain three times daily) but the result was only a slight and temporary reduction in the degree of dribbling. Tincture of stramonium (up to 30 minims every four hours) produced a similar result. It was then decided to try the effect of $X$-ray irradiation to the parotid glands on both sides. $J$. was given daily treatment in hospital for one week, and for about six weeks afterwards there was slight improvement in the 
degree of dribbling, probably because less saliva was produced. However, several weeks later dribbling was as profuse as before.

The following 'year bilateral ligation of Stensen's duct from inside the cheek was performed, but again the result was not satisfactory and there was only slight improvement of the dribbling. One year later an examination of the parotid ducts was carried out by probing. On the left side the ligature was found to be adequate, but on the right side Stensen's duct was found to be patent throughout its length. The left submaxillary gland was then removed. The operation resulted in considerable improvement in dribbling. By the end of each morning there were only a few stains on his shirt-front, compared with the previous wet 'dickie' area. Dribbling occurred only when close mental concentration made him forget to swallow excess saliva. By the beginning of the following year there had been a further improvement in dribbling and he now had to change his shirt during the day only twice a week, compared with twice a day prior to operation. Towards the end of the year there was some relapse in the degree of dribbling, and the right submaxillary gland was removed.

After this last operation dribbling became negligible.

Our experience has been that if the child has not acquired control of drooling by the time he reaches the age of formal schooling (between the age of six and eight years), he is usually very distressed by the constant soiling of school books, papers, equipment and table-top activities and usually resents having to wear bibs. In desperation we have suggested the use of cotton towelling wristbands to dab wet chins as this may be more socially acceptable for the older child. Many of the children have wet chins and sodden top clothes and require several changes of clothing a day. Depending on how fastidious the parents are, we have known children who have had $28-30$ bib changes a day in an attempt to keep them dry. The social stigma of drooling increases as the child gets older and parents and siblings find it increasingly difficult to be 'loving' and 'patient' with the drooling member of the family Although the patient may be unaware of his drooling on a physical level he is made aware of it by the looks and stares of strangers and the remonstrations of those in the immediate family circle.

The social and economic problems faced by the older adolescent and young adult drooler were vividly brought to our attention early in 1973 when we were asked to assist an intelligent, 21 year old, self-conscious, spastic hemiplegic female who had very severe involvement of oral musculature and who had no control of drooling. Habitual mouth position was open and isolated movements of lips, tongue and jaw were virtually impossible. Any attempt to move parts of the speech mechanism (e.g. protrude or elevate her tongue) or to vocalize or communicate orally, caused a marked increase of tension in face, jaw, cheek and neck muscles, accompanied by a strong tempero-mandibular joint slip. She used a spelling board to spell out individual letters in communicating. Basic functions of chewing, sucking and swallowing were very poor and there was much loss of liquid in drinking. She drooled continuously; on effort, amount of drooling was increased. She was living in a 
centre for adult cerebral palsied patients in Natal where her occupation was to assist in the kitchen. The inability to control her drooling was both a threat to her job and a serious embarrassment to her. There appeared to be no automatic swallowing pattern and pooling of saliva was so excessive, and oral musculature so severely impaired that prognosis for acquiring control of drooling using conventional methods was considered to be hopeless. The possibility of oral surgery was considered and fortunately, at the time, a paper by Brody became available.

In his paper, Brody ${ }^{1}$ acknowledged that the pathophysiology of drooling and the principles of its surgical correction were first described by Theodore Wilkie, ${ }^{17}, 18$ a Canadian Plastic Surgeon. Wilkie noted the significance of tongue function in the control of saliva while observing cineradiographs taken to analyse the palatal movement of cleft palate patients. He concluded that swallowing was divided into oral and pharyngeal phases. In the normal person in the oral phase of swallowing, the co-ordinated tongue first manipulates the food and/or saliva onto it and then forms a cup which seals against the hard palate sweeping the bolus posteriorly and depositing it into the pharynx. This initiates the second phase, the pharyngeal phase which is automatic. When one considers that twenty-one muscles are used in a split second during a swallowing movement and that the average person swallows approximately two thousand times a day, one appreciates how difficult it is for the cerebral palsied child to manipulate the saliva and/or food back into position for swallowing. The cerebral palsied child's tongue discoordinately slaps against the palate, sending the oral contents in all directions with only a portion reaching the pharynx. Brody ${ }^{1}$ assumes that the pharyngeal phase of swallowing in cerebral palsy is relatively normal, if the child has had no respiratory or nutritional difficulties, and that the main cause of drooling is the ineffective tongue co-ordinating mechanism.

Approximately 1,000 to $1,500 \mathrm{cc}$ of saliva are produced daily. 90 to $95 \%$ of saliva is produced by the submaxillary and parotid glands while the remainder is derived from buccal and sublingual glands. The submaxillary glands empty into the mouth through ducts located under the tongue anteriorly in the floor of the mouth and the parotid ducts emerge in the upper cheeks at the level of the second maxillary motor. Two or more salivary glands can be removed with relative ease, but parotid resection is more complicated with considerable risk to the facial nerve. ${ }^{7}$

In 1967, Wilkie ${ }^{17}$ postulated that if the saliva could enter directly into the pharynx, the need for tongue manipulation would be by-passed, sufficient saliva would remain for mastication, pooling of saliva in the front of the mouth would cease and drooling should be controlled. Working on the basis that a strip of mucosa could be buried submucosally and would spontaneously tube itself, he lengthened the parotid duct and rerouted it into the tonsillar fossa. In this way the saliva from the parotid secretions by-passed the tongue and were deposited far enough posteriorly for the pharyngeal phase of swallowing. This substantially decreased the amount of saliva in the anterior portion of the mouth. Wilkie first described two patients who were successfully treated for drooling by the above described surgical procedure, ${ }^{17}$ and later reported 
a series of eight patients treated in a five year period including his two original cases. ${ }^{18}$ Seven of the eight cases required a second surgical procedure viz. submandibular gland resection. Significant improvement in control of drooling was recorded in all eight patients.

Brody' reported on a large series of over sixty patients, aged between 6-65 years, who had the combined procedure of bilateral submaxillary gland resection and posterior transplantation of the parotid duct. Approximately onehalf of these patients had a primary diagnosis of severe mental retardation (IQ range $15-60$ ) with or without cerebral palsy. The other half of his series were primarily cerebral palsied with lesser degrees of intellectual impairment.

Of Brody's first 60 patients, 55 had sufficient improvement in their drooling to consider the surgery successful. Of this group, approximately two-thirds had no residual drooling and minimal or no side effects. Stenosis of the orifice of the new duct occurred in 13 patients representing 16 of 120 ducts. Brody 1 stated that recent refinement of the operation has lowered the incidence of stenosis.

The surgical procedure described by Wilkie ${ }^{17}$ was employed by Dr. Isidore Kaplan to successfully alleviate our young adult's drooling problem. Subsequently nineteen other patients, ranging in age from 4 years 9 months to 21 . years, had the bilateral procedure of submaxillary gland excision with parotid duct elongation and relocation. Fourteen patients were males and six were females, and all had been diagnosed as uncontrollable droolers who had not re: sponded to conservative measures.?

The remainder of this paper consists of a follow-up report on Dr. Kaplan's series of cases based on the results of a pre-and post-operative oral surgery questionnaire completed by speech therapists working at Cerebral Palsy Schools in the Republic of South Africa. It was hoped that analysis of the results of the questionaires would provide us with additional information on the problem of drooling in cerebral palsy. Information was obtained on nineteen of the twenty patients who underwent oral surgery between October 1973 and De. cember 1976. As this is a relatively small sample, detailed statistical analysis of the results was not undertaken. The writer has attempted to determine response trends in possible relationships between severity of drooling and the following factors:-

(a) type of cerebral palsy.

(b) degree of involvement.

(c) intelligence.

(d) presence of a complicating oral sensory loss and/or apraxia.

(e) habitual mouth position and swallowing pattern.

(f) oral communicative ability.

(g) length of period of pre-operative speech therapy.

On the post-operative side we were interested in comparing: (a) the surgeon's evaluation of results in each case with the speech therapists' rating of the success of oral surgery and whether these assessments agreed with the par?nts' opinions of the results of surgery, (b) the incidence and types of post-operative complications, (c) the incidence and types of post-operative behavioural 
disturbances. Many of these children are subjected to several orthopedic surgical procedures during their formative years and the psvchological effects of additional surgery should not be overlooked. ${ }^{12}$

Patients attended the following Cerebral Palsy Schools or Adult Cerebral Palsy Centre.

Name of School

No. of Patients
Case No. as

in Table I

Forest Town Cerebral

Palsy School

$4,5,10,11,12$.

Nuwe Hoop Cerebral

Palsy School

1

1

Muriel Brand Cerebral

Palsy School

2

8,15 .

Pretoria Cerebral Palsy

School

2

9,14 .

West Rand Cerebral Palsy

School

6

$2,6,7,13,16,17$.

Pevensy Place Adult

Cerebral Palsy Centre

Two patients were not attending Cerebral Palsy Schools and no questionaires were completed on them. Information on these two patients was obtained from the surgeon's files (Case Numbers 3 and 8 as listed on Table I).

\begin{tabular}{|c|c|c|c|c|c|}
\hline $\begin{array}{l}\text { Case } \\
\text { No. }\end{array}$ & $\begin{array}{l}\text { Age } \\
\text { Surg } \\
\text { Ya }\end{array}$ & $\begin{array}{l}\text { at } \\
\text { Mths }\end{array}$ & Type of Cerebral Palsy & $\begin{array}{l}\text { Degree of } \\
\text { Involvement }\end{array}$ & Most Recent IQ Assessment \\
\hline $\mathbf{I}$ & 4 & 9 & Athetoid and Spastic & Quadriplégia & $\begin{array}{l}\text { C.A. 4,7; M.A.2,11-Reynell Verbal Comprehention } \\
\text { M.A. 2,2.P.P.V.T. (Peabody) }\end{array}$ \\
\hline 2 & 7 & & Aphasia Dysarthria & Na Phys. Inv. & IQ 69.Snijders-Oomen Non Vebal Intelligence Scale. \\
\hline 3 & 6 & & Not Knawn & Not Known & Not Known \\
\hline 4 & 7 & 6 & Spastic & Qundriplegia & IQ 6I-OId SA.1.S. IQ 48-New S.A.I.S. \\
\hline 5 & 7 & 9 & $\begin{array}{l}\text { Spastic, Pseuda Bubar } \\
\text { Palsy, Apraxia }\end{array}$ & $\left.\begin{array}{l}\text { Bilateral } \\
\text { Hemiplegia }\end{array}\right\}$ & IQ 52.Stanford Binet; IQ 56-Columbia \\
\hline 6 & 11 & & Spastic and Athetoid & Quadriplegia & IQ 77-Snijders-Oomen Non Verbal Intelligence Scale. \\
\hline 7 & 11 & & Athetoid & Quadriplegia & IQ 60-Columbia Mental Maturity Scale. \\
\hline 8 & 11 & 8 & Athetoid & Not Known & IQ I07.New S.A.JS. \\
\hline 9 & 11 & 8 & Spastic and Athetoid & Quad riplegia & IQ 85-Columbia Mental Maturity Scale. \\
\hline 10 & 12 & 7 & Spastic & $\left.\begin{array}{l}\text { Bilateral } \\
\text { Hemiplegia }\end{array}\right\}$ & IQ 83-New S.A.IS. \\
\hline II & 12 & 11 & Spastic & $\left.\begin{array}{l}\text { Bilateral } \\
\text { Hemiplegia }\end{array}\right\}$ & IQ 62-New S.A.I.S. \\
\hline 12 & 13 & 3 & Spastic Athetoid & Quadriplegia & IQ 55.PP.V.T. (Peabody) \\
\hline 13 & 14 & 3 & Spastic & Quadriplegia & IQ 64-Columbia. \\
\hline 14 & 15 & & Spastic & Quadriplegia & IQ 50-Ravens Ptogressive Matrices. \\
\hline 15 & 16 & 7 & Spastic & Quadriplegia & IQ 73-New S.A.I.S. \\
\hline 16 & 17 & & Spastic & Quadriplegia & IQ 73-Ravens Progressive Matrices. \\
\hline 17 & 17 & 2 & Spastic & Hemiplegia & IQ 86-Old S.A.I.S. \\
\hline 18 & 18 & & Spastic & Quadriplegia & Not Known. \\
\hline 19 & 21 & & Spastic & Hemiplegia & Not Known. \\
\hline
\end{tabular}

TABLE I Summary of selected features from the case histories of the droolers. 


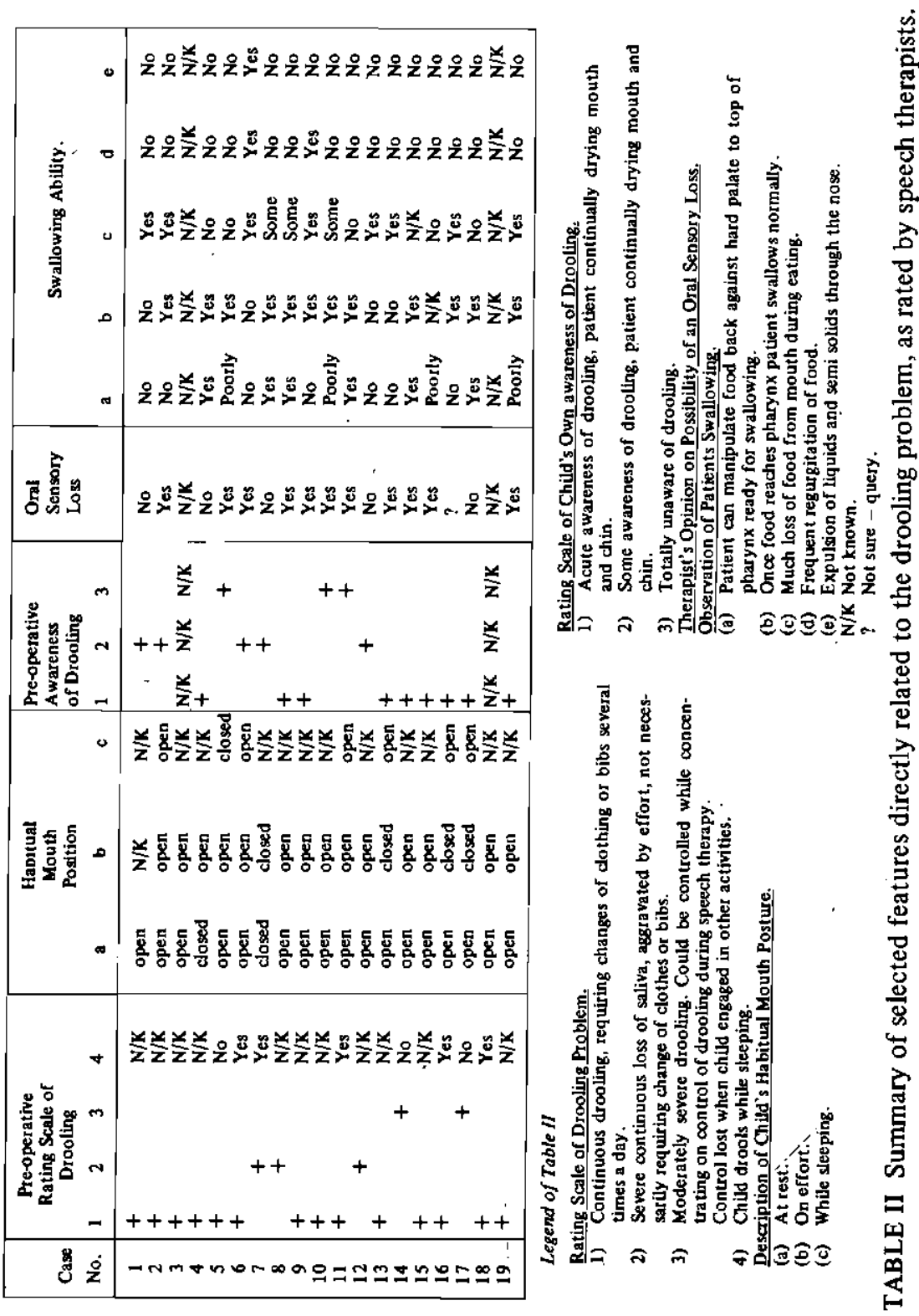


Table I indicates that the majority of severe droolers are spastic or mixed spastics and athetoids. Only two patients were diagnosed as athetoids and one as predominantly athetoid with some spasticity. When one considers degree of involvement, the majority of patients who are severe droolers are the physically more severely affected ones, i.e. quadriplegics or double hemiplegics (involvement of all four limbs, arms more than legs and involvement of bulbar musculature.) There was only one patient in the series who had no physical involvement, two were hemiplegics and two whose degree of involvement was not known. It is difficult to make firm statements about intelligence because of the variety of intelligence tests used. In the sixteen patients where some formal assessment was available IQ scores ranged from $50-107$. Twelve of the sixteen patients had intelligence quotients below 80 .

Table II shows that fourteen of the nineteen patients were rated by the speech therapists as continuous droolers, requiring several changes of clothing or bibs each day. Three were rated as severe droolers not necessarily requiring change of clothes or bibs. Two were rated as moderately severe droolers i.e. drooling could be controlled while concentrating on it but control broke down when the child engaged in other activities. The answer to the fourth question, whether the child drooled while sleeping, was in most cases not known. Habitual mouth position at rest and on effort was open in the majority of cases as was to be expected. Mouth position while sleeping was not known in twelve of the nineteen patients. As far as pre-operative awareness of drooling was concerned, nine patients were classified as being acutely aware of their drooling, five had some awareness and three were totally unaware of their drooling. The Speech Therapists felt that eleven of the patients had a possible oral sensory loss, five had no oral sensory loss, no information was available on two cases and a therapist was not sure whether there was an oral sensory loss in one case. When swallowing ability is considered, we see that eleven of the nineteen patients had problems projecting food from the front to the back of the mouth. Once the bolus of food reached the pharynx twleve of the nineteen subjects could swallow normally, four had problems in the pharyngeal phase of swallowing as well. No information was available on swallowing on the remaining three patients. Ten of the nineteen patients had some or much loss of food while eating. Two patients frequently regurgitated their food and one patient had problems of liquids and semi-liquids being expelled through the nose.

Table III does not contain information on years of pre-operative speech therapy and frequency of treatments per week is not set out in detail as the number of years of pre-operative therapy varied between one and ten years and number of weekly sessions between one and five. A wide variety of methods and techniques was used so meaningful comparisons cannot be made.

Results of Table III indicate a complicating apraxic component in seven out of the sixteen cases on whom questionaires were completed. i.e. an incidence of $43 \%$ - a higher incidence of apraxia in a cerebral palsied group than one normally expects to find. Fifty per cent of the patients were unable to communicate orally and among the remaining 50\%, half had very distorted speech with poor speech intelligibility and the other half were patients with articula- 


\begin{tabular}{|c|c|c|c|c|c|}
\hline \multirow[t]{2}{*}{$\begin{array}{l}\text { Case } \\
\text { No. }\end{array}$} & \multirow[t]{2}{*}{ Apraxia } & \multicolumn{3}{|c|}{$\begin{array}{l}\text { Rating Scale of } \\
\text { Severity of } \\
\text { Dysarthria/Apraxia }\end{array}$} & \multirow[t]{2}{*}{ Method of Communication. } \\
\hline & & 1 & 2 & 3 & \\
\hline 1 & No & + & & & Points. Vocalizes. Simple Gesture. \\
\hline 2 & Yes & & + & & Distorted oral communication. \\
\hline 3 & $N / K$ & + & ++1 & & Not Known. \\
\hline 4 & No & & & +0 & $\begin{array}{l}\text { Communicates orally. Good intel- } \\
\text { ligibility. }\end{array}$ \\
\hline 5 & Yes & + & & & $\begin{array}{l}\text { Eye Pointing. Communication } \\
\text { Board. }\end{array}$ \\
\hline 6 & Yes & + & & & Gesture \& Typing. \\
\hline 7 & Yes & & + & & Communication Board. \\
\hline 8 & No & & & + & Distorted Oral Communication. \\
\hline 9 & No & + & & & $\begin{array}{l}\text { Gesture. Communication Board } \\
\text { and Typing. }\end{array}$ \\
\hline 10 & No & & + & & $\begin{array}{l}\text { Very distorted oral communi- } \\
\text { cation. }\end{array}$ \\
\hline 11 & No & & & +0 & $\begin{array}{l}\text { Communicates orally. Reasonable } \\
\text { intelligibility. }\end{array}$ \\
\hline 12 & Yes & + & & & $\begin{array}{l}\text { Gesture. Vocalisation. Communi- } \\
\text { cation Board. }\end{array}$ \\
\hline 13 & Yes & + & & & Gesture. Communication Board. \\
\hline 14 & No & & + & & Isolated Vocalisations. Types. \\
\hline 15 & $N / K$ & & & + & $\begin{array}{l}\text { Very distorted oral communi- } \\
\text { cation. }\end{array}$ \\
\hline 16 & Yes & + & & & Gesture and Typing. \\
\hline 17 & No & & & + & $\begin{array}{l}\text { Communicates orally but } \\
\text { distorted. }\end{array}$ \\
\hline 18 & $\mathrm{~N} / \mathrm{K}$ & - & - & - & Not known. \\
\hline 19 & No & + & & & Points. Simple Spelling Board. \\
\hline
\end{tabular}

Legend: $\quad+=$ Excluded in totals. :

- = Communicates orally. Reasonably-good intelligibility.

$\mathrm{N} / \mathrm{K}=$ Not Known.

Rating Scale of Severity of Dysarthria/Apraxia.

1) Totally unable to communicate orally.

2) Attempts to communicate orally, but severely distorted.

3) Communicates orally but has articulatory + phonatory errors.

TABLE III Summary of selected features related to the speech of the patients.

tory and phonatory errors. One child (case No. 4) had speech completely within normal limits although she was a severe drooler and another child (case No. 11) has intelligible speech after several years of speech therapy. 
Table IV consists of a comparison between the surgeon's evaluation of results achieved and the various speech therapists' ratings of the success of the surgical intervention. Details of post operative complications and the parents' evaluation of surgery are also included.

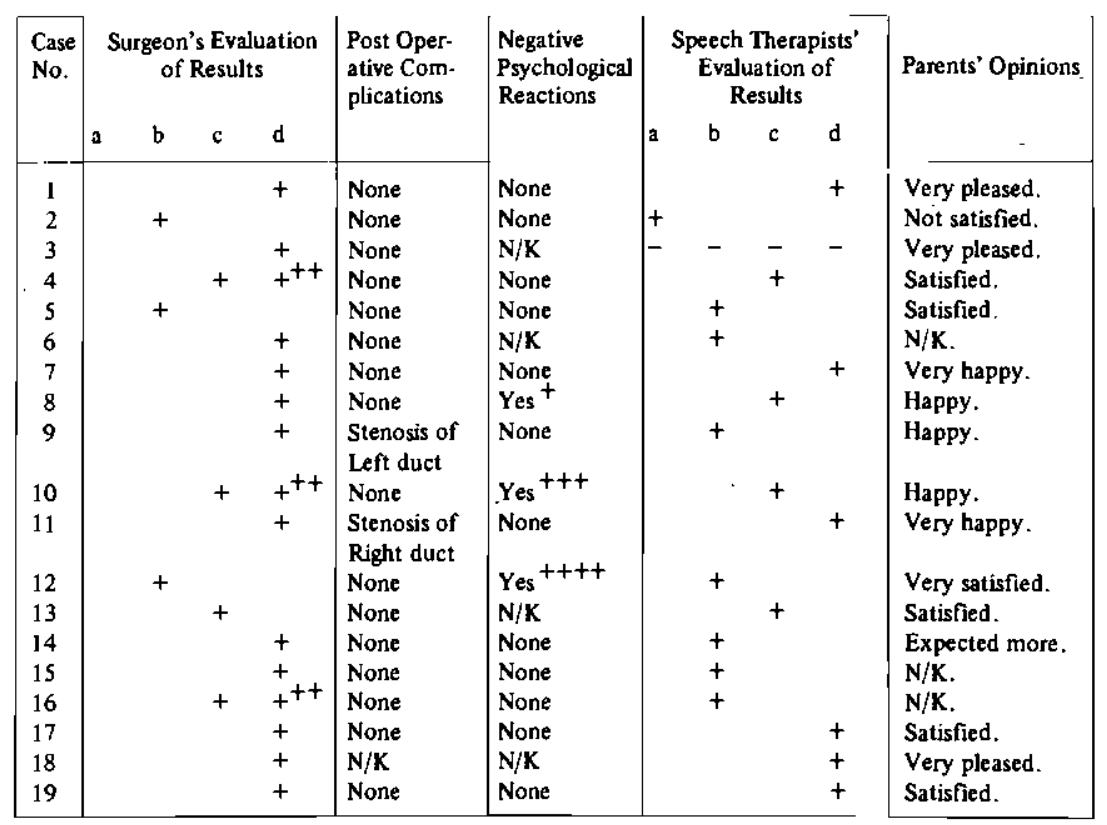

Legend: $\mathrm{N} / \mathrm{K}=$ Not known.

$++\quad 3$ cases were evaluated by the surgeon as between good and excellent and have been tabulated accordingly. They were not however counted twice in final totals.

$+\quad$ Some behavioral disturbances were noted post operatively, the speech therapist felt probably more due to marital strife in the home.

+++ Weepy and insecure for one week after discharge from hospital, had been fine while in hospital.

++++ Very upset for about one month post operatively then settled down.

TABLE IV Summary of the evaluation of selected features of surgery.

Examination of Table IV shows exact agreement between the surgeon's evaluation of results and the various speech therapists' ratings in ten of the eighteen cases i.e. 55\%. The surgeon did not rate any case as representing no improvement, i.e. drooling problem unchanged, but the speech therapist and parents gave one case this rating. (The surgeon evaluated this case as fair). 
Four more cases were rated as being fair by the speech therapists than by the surgeon. Twelve of the nineteen patients achieved an excellent result according to the surgeon and four a good result. The speech therapists' figures for these two categories were five and five respectively. Stenosis occurred in only two of the thirty-eight ducts operated on i.e. $5,2 \%$ of cases. No instances of bilateral stenosis occurred. Occurrence of stenosis was not related to whether the parotid ducts were tubed or not.? This is a lower incidence of stenosis than that reported by Brody1 where stenosis occurred in 13,3\% of cases. Three of the fifteen patients on whom information was available had negative psychological reactions to the oral surgery. None of these lasted longer than one month. Fourteen of the sixteen parents were satisfied or highly delighted with the results of oral surgery, one set of parents were dissatisfied, one expected more and information was not available on three cases.

Additional positive results were mentioned on two of the cases. In case I, the speech therapist commented on the fact that the child had an immediate increase in appetite and a gradual disappearance of halitosis which had been a problem pre-operatively. One other case was reported as being very thirsty pre-operatively but not post-operatively.

\section{RESULTS AND CONCLUSIONS}

The majority of droolers in this study were spastics or spasticity was the dominant disability when more than one disability was present. As was to be expected, most of these patients were severely involved in terms of degree of disability. Seventy-five percent of them had intelligence quotients below eighty as assessed on various scales. Habitual mouth position was open in seventeen of the nineteen patients on whom questionnaires had been completed.

An oral sensory loss was suspected in eleven of eighteen patients and seven out of sixteen or $43 \%$ were considered to be apraxic in addition to their severe dysarthria. Fifty percent of the group were totally unable to communicate orally, twenty-two percent could communicate verbally but with very poor intelligibility and the speech of the rest of the group ranged from reasonable intelligibility to normal speech.

There was a fifty-five percent agreement in rating improvement between the speech therapists and the surgeon. Agreement in rating improvement between the therapists and the parents was higher. Only one child was considered by the speech therapist and his parents as totally unchanged post-operatively and as a fair result by the surgeon. In all the other patients, improvement in control of drooling ranged from fair to excellent. There has been a very low incidence of stenosis and fistula formation which Kaplan attributed to the method of creating a V-shaped, rather than a circular, orifice of sufficient width in the tonsillar fossa. ${ }^{7}$

Study of the four cases where the pharyngeal phase of swallowing was considered abnormal by the speech therapists reveals that three out of the four had a poorer surgical result than the rest of the group. Conclusions cannot be 
drawn from such limited data but more detailed pre-operative assessments of swallowing including cineradiography will be done on future patients. This may enable us to predict more accurately the kind of results to expect from oral surgery and be able to advise parents accordingly. It is also incumbent upon the speech therapist to inform both the patient and parents about the post operative hospital treatment which includes administration of fluids and antibiotics intravenously for the first forty-eight hours, intra-oral suction and routine oral hygiene and the restriction of intake to only clear fluids. On the third day a soft diet is permitted with mouth washes and continuous oral hygiene. Frequent encouragement to swallow by the nursing staff is important and regular visits by the speech therapist help to maintain the morale of patients and family. Most patients are discharged on the seventh or eighth day. All patients have fairly marked facial oedema for a while post-operatively.

Adequate pre-operative preparation for hospitalization reduces the likelihood of psychological trauma occurring post-operatively.

Oral surgery is not suggested as a panacea for all cerebral palsied droolers. The twenty cases who underwent the surgical procedure described in this paper represent a very small percentage of patients in cerebral palsy schools in the Republic. It is suggested as a form of treatment which should be offered to persistent droolers who have not shown improvement with other methods. The positive psychological effects observed post-operatively in nineteen of the twenty patients and their families were quite dramatic. Many of the older patients actually verbalized that the drooling was the most distressing and unpleasant feature of all their disabilities. Persistence of drooling into late adolescence and early adulthood is accompanied by self-consciousness and feelings of inferiority and inadequacy which increase problems in job placement, even in sheltered workshop situations.

\section{ACKNOWLEDGEMENTS}

The writer gratefully acknowledges the interested assistance of Dr. G. Brody, Rancho Los Amigos Hospital, California for introducing us to the field of oral surgery and to the late Dr. I. Kaplan who carried out the oral surgery. His patience and kindness towards both patients and paramedical colleagues will always be remembered. Sincere thanks to the speech therapists who completed the questionnaires from which the data was drawn.

\section{REFERENCES}

1. Brody, G. S. (1972): The Surgical Control of Drooling in Cerebral. Palsy. Paper presented to the American Academy for Cerebral Palsy.

2. Brody, G. S. (1973): The Surgical Control of Drooling in Cerebral Palsy. Abstract of paper presented to American Academy for Cerebral Palsy. Devel. Med. and Child Neurol, 15, No. 2. 
3. Diamant, M. (1974): A treatment for Drooling in Children with Cerebral Palsy. J. Laryngology Otology. VLXXXVIII, No. 1.

4. Enfors, B. and Lundberg, A. (1969): Die Behandlung der Hyper Salivation bei Kinder in mit Zerebral paresen. Paper presented at a meeting, Dusseldorf.

5. Garber, N. B. (1971): Operant Procedures to Eliminate Drooling Behaviour in a Cerebral Palsied Adolescent. Devel. Med. Child Neurol., 13, 641 .

6. Kaplan, I., and Shavell, A. (1974): The Surgical Control of Drooling. Film/Slide demonstration and Presentation to Cerebral Palsy Division of the National Council for the care of Cripples in South Africa. June 25 th, President Hotel, Johannesburg.

7. Kaplan, I. (1977): Results of the Wilkie Operation to Stop Drooling in Cerebral Palsy. Plastic and Reconstructive Surgery. 59, 5, p. 646.

8. Mueller, H. (1972): Facilitating Feeding and Pre-Speech. In Physical Therapy Services in the Developmental Disabilities. Pearson, P. et al. (Eds), C. C. Thomas. Springfield, 111.

9. Mueller, H. (1974): Handling the Young Cerebral Palsied Child at Home, W. Heinemann. Med. Books 2nd. Ed.

10. Mueller, H. (1976): Notes from Speech Therapy Workshop. Forest Town Cerebral Palsy School, July 1976.

11. Palmer, M. (1947): Normalization of Chewing, Sucking and Swallowing Reflexes in Cerebral Palsy: A Home Programme. J. Speech Dis., 12 , No. 4.

12. Reynell, J. (1965): Post Operative Disturbances Observed in Children with Cerebral Palsy. Devel. Med. Child Neurol. 7, 360-376.

13. Rood, M. (1969): Sensory Stimulation Techniques. Notes from the Rood Course. S.A. Physiotherapy Soc.

14. Shavell, A. (1973): Home Speech Therapy Programme for the Young Cerebral Palsied Child. Forest Town Cerebral Palsy School.

15. Shavell. A. (1977): Chańging Attitudes and Approaches to Speech Therapy with Cerebral Palsied Patients. S.A. Cerebral Palsy J. 21.

16. Westlake, H. and Rutherford, D, (1961): Speech Inerapy for the Cerebral Palsied. National Soc. for Crippled Children and Adults, Inc.

17. Wilkie, T:F. (1967): The problem of Drooling in Cerebral Palsy - a surgical approach. Canadian J. Surg., 10:60.

18. Wilkie, T. F. (1970): The Surgical Treatment of Drooling: A Follow up Report of Five Years Experience. Plastic and Reconstruction Surg. ery. $\mathrm{V}, 45$, No. 6 .

19. Worster - Drought, C. (1974): Suprabulbar Paresis. Devel'Med. Child Neurol, 16, 1. Supplement No. 30. 